\title{
PERAN IMUNITAS HUMORAL PADA PENYAKIT SYSTEMIC LUPUS ERYTHEMATOSUS (SLE)
}

\author{
Sri Wahyuni ${ }^{1}$ \\ ${ }^{1}$ Bagian Biokimia Prodi Pendidikan Dokter Fakultas Kedokteran Universitas Malikussaleh \\ Corresponding Author : sri.wahyuni@unimal.ac.id
}

\begin{abstract}
Abstrak
Systemic Lupus Erythematosus (SLE) adalah suatu kelainan autoimun multisistem kronik yang ditandai oleh autoantibodi dan kompleks imun yang berkaitan dengan manifestasi klinis dan kerusakan jaringan yang beragam dan luas. Beberapa defek dari komponen imunologi multipel berperan penting dalam patogenesis SLE. Abnormalitas imunologi pada SLE meliputi kemampuan untuk menghasilkan autoantibodi patogenik, hilangnya regulasi sel limfosit $\mathrm{B}$ dan $\mathrm{T}$, serta defective clearance dari autoantigen dan kompleks imun. Faktor genetik, imunologik dan hormonal serta lingkungan diduga berperan dalam patofisiologi SLE. Tulisan ini mengkaji respon imun humoral sebagai salah satu patogenesis SLE.
\end{abstract}

Kata Kunci : systemic lupus erythematosus, imunitas humoral; limfosit B

\section{HUMORAL IMMUNITY ROLE IN SYSTEMIC LUPUS ERYTHEMATOSUS (SLE)}

\begin{abstract}
Systemic lupus erythematosus (SLE) is a chronic multisystem autoimmune disorder characterized by autoantibodies and immune complexes associated with clinical manifestations and tissue damage varied and extensive. Some defects of multiple immunological components play an important role in the pathogenesis of SLE. Immunological abnormalities in SLE include the ability to produce pathogenic autoantibodies, the loss of regulation of $\mathrm{B}$ and $\mathrm{T}$ lymphocytes, and defective clearance of autoantigens and immune complexes. Genetic factors, immunologic and hormonal and environmental alleged role in the pathophysiology of SLE. This paper discusses the humoral immune response as one of the pathogenesis of SLE.
\end{abstract}

Keyword: systemic lupus erythematosus, humoral immunity; B lymphocytes 


\section{PENDAHULUAN}

Lupus eritematosus sistemik (Systemic Lupus Erythematosus/SLE) adalah kelainan inflamatori multisistem yang kronik, rekuren dan fatal sehingga sulit untuk didiagnosis. Penyakit ini tidak mempunyai marker diagnosis tunggal dan harus diidentifikasi melalui gabungan kriteria klinis dan laboratorik. Diagnosis akurat dari SLE penting karena pengobatan dapat mengurangi morbiditas dan mortalitas. ${ }^{1}$

Lupus eritematosus sistemik merupakan penyakit autoimun prototipik yang ditandai oleh produksi antibodi terhadap komponen sel nukleus yang berhubungan dengan manifestasi klinis yang luas. Lupus eritematosus sistemik merupakan penyakit inflamasi autoimun kronis dengan etiologi yang belum diketahui serta manifestasi klinis, perjalanan penyakit dan prognosis yang sangat beragam. Penyakit ini terutama menyerang wanita usia reproduksi dengan angka kematian yang cukup tinggi. ${ }^{2}$

Insiden tahunan SLE di Amerika Serikat sebesar 5,1 per 100.000 penduduk, sementara prevalensi SLE di Amerika dilaporkan 52 kasus per 100.000 penduduk, dengan rasio gender wanita dan laki laki antara 9-14:1. Belum terdapat data epidemiologi SLE yang mencakup semua wilayah Indonesia. Data tahun 2002 di RSUP Cipto Mangunkusumo (RSCM) Jakarta, didapatkan 1,4\% kasus SLE dari total kunjungan pasien di poliklinik Reumatologi Penyakit Dalam, sementara di RS Hasan Sadikin Bandung terdapat 291 Pasien SLE atau 10,5\% dari total pasien yang berobat ke poliklinik reumatologi selama tahun 2010. Manifestasi klinis SLE sangat luas, meliputi keterlibatan kulit dan mukosa, sendi, darah, jantung, paru, ginjal, susunan saraf pusat (SSP) dan sistem imun. ${ }^{2}$

\section{Etiologi dan Perjalanan Penyakit}

Faktor genetik, imunologik dan hormonal serta lingkungan diduga berperan dalam patofisiologi SLE. ${ }^{2}$ Penyakit diawali dengan fase preklinis yang ditandai oleh autoantibodi yang serupa dengan penyakit autoimun sistemik lainnya dan menjadi penyakit yang spesifik secara klinis pada fase autoimun. Kerusakan dini sebagian besar berhubungan dengan penyakit, sedangkan kerusakan lamban seperti infeksi, aterosklerosis, dan keganasan biasanya berhubungan dengan komplikasi penyakit dan terapi imunosupresan. ${ }^{3}$ 


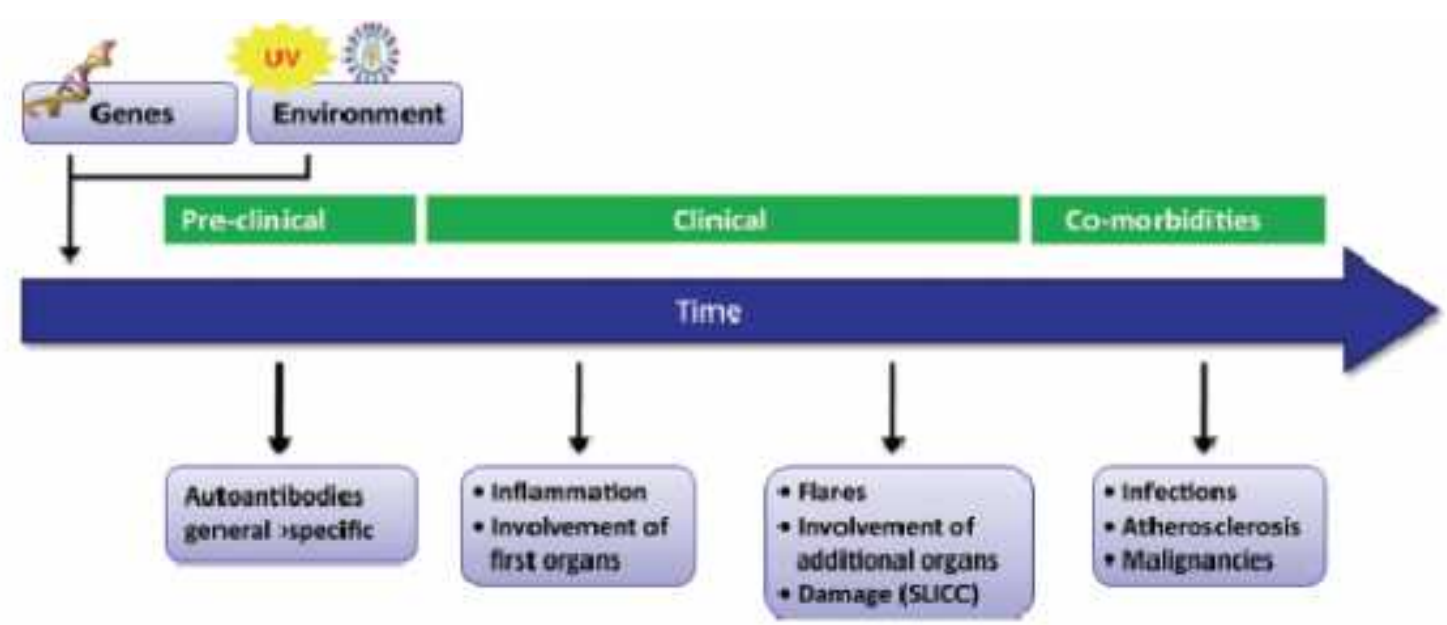

Gambar 1. Perjalanan penyakit SLE ${ }^{3}$

a) Faktor genetik ${ }^{3}$

Genome-wide assosiation studies (GWAS) menggunakan ratusan hingga ribuan marker single nucleotide polymoprhism (SNP) untuk penyakit SLE. GWAS telah mengkonfirmasi kepentingan dari gen yang berkaitan dengan respon imun dan inflamasi (HLA-DR, PTPN22, STAT4, IRF5, BLK, OX40L, FCGR2A, BANK1, SPP1, IRAK1, TNFAIP3, C2, C4, CIq, PXK), DNA repairs (TREX1), adherence of inflammatory cells to the endothelium (ITGAM), dan tissue response to injury (KLK1, KLK3). Temuan ini mengedepankan pentingnya jalur sinyal Toll-like receptor (TLR) dan interferon tipe 1 (IFN). Gen STAT4 yang merupakan faktor risiko genetik terhadap artritis rheumatoid dan SLE dikaitkan dengan kejadian SLE berat. Salah satu komponen penentu dari jalur-jalur ini adalah TNFAIP3 yang telah diketahui berperan dalam 6 (enam) kelainan autoimun termasuk SLE.

b) Efek epigenetik ${ }^{3}$

Risiko untuk penyakit SLE dapat dipengaruhi oleh efek epigenetik seperti metilasi DNA dan modifikasi histon pasca translasi yang dapat terjadi baik diturunkan atau modifikasi oleh lingkungan. Epigenetik menggambarkan adanya perubahan yang diwariskan dalam ekspresi gen yang disebabkan oleh mekanisme selain perubahan urutan basa DNA. Beberapa penelitian juga telah menunjukkan hubungan metilasi DNA pada SLE.

c) Faktor lingkungan

Sinar ultraviolet merupakan pemicu SLE yang berasal dari lingkungan. Paparan UVA2 dan UVB melalui proses tanning kulit untuk kecantikan dapat mengeksaserbasi peyakit kulit pada pasien dengan kelainan ini. Namun, akibat dari tidak terpapar matahari adalah defisiensi vitamin D dimana berkaitan juga dengan aktivitas penyakit. Faktor lingkungan 
lainnya adalah merokok, infeksi, estrogen eksogen, obat-obatan, agen biologis dan pestisida, alkohol, dan vaksinasi. ${ }^{4,5}$

d) Faktor hormonal $^{4}$

Insiden SLE meningkat setelah pubertas dan menurun setelah menopause. Tingkat keparahan penyakit beragam saat hamil dan siklus menstruasi. Pada studi kohort terhadap 238.308 wanita yang diamati secara prospektif antara tahun 1976 dan 2003, faktor-faktor seperti menarch dini, pemakaian kontrasepsi oral, menopause dini, menopause surgikal, dan penggunaan hormon pasca menopause berkaitan dengan meningkatnya risiko dari penyakit SLE.

Peran dari hormon pada penyakit SLE antara lain: ${ }^{6}$

1. Kerentanan terhadap perkembangan SLE

a. Kadar estrogen endogen rendah bersifat protektif

b. Nilai androgen rendah pada laki-laki meningkatkan risiko

c. Pemakaian estrogen eksogen pada wanita meningkatkan risiko

2. Profil hormon dan aksis hipotalamus pituitasi pada pasien SLE

a. Meningkatnya metabolisme estrogen menjadi metabolit yang lebih poten (pada kedua jenis kelamin)

b. Nilai androgen rendah (pada kedua jenis kelamin)

c. Nilai androgen berkorelasi terbalik dengan aktifitas penyakit pada wanita

d. Bukti awal adanya defek aksis HPA pada pasien SLE wanita yang tidak diterapi

3. Aktifitas hormon dan prognosis SLE

a. Aktifitas penyakit cenderung menurun setelah menopause

b. Flares pada SLE dapat terjadi selama periode perubahan cepat hormon

c. Fluktuasi siklus aktifitas penyakit pada wanita selama siklus menstruasi

d. Pasien dengan onset SLE pasca menopause memiliki aktifitas penyakit lebih rendah dan prognosis lebih baik

\section{Manifestasi Klinis, Klasifikasi dan Diagnosis ${ }^{2}$}

Terkait dengan dinamisnya perjalanan penyakit SLE, maka diagnosis dini tidaklah mudah ditegakkan. SLE pada tahap awal, seringkali bermanifestasi sebagai penyakit lain misalnya artritis reumatoid, glomerulonefritis, anemia, dermatitis dan sebagainya. Ketepatan diagnosis dan pengenalan dini penyakit SLE menjadi penting.

Kecurigaan akan penyakit SLE perlu dipikirkan bila dijumpai 2 (dua) atau lebih kriteria sebagaimana tercantum di bawah ini, yaitu: 
1. Wanita muda dengan keterlibatan dua organ atau lebih.

2. Gejala konstitusional: kelelahan, demam (tanpa bukti infeksi) dan penurunan berat badan.

3. Muskuloskeletal: artritis, artralgia, miositis

4. Kulit: ruam kupu-kupu (butterfly atau malar rash), fotosensitivitas, lesi membrana mukosa, alopesia, fenomena Raynaud, purpura, urtikaria, vaskulitis.

5. Ginjal: hematuria, proteinuria, silinderuria, sindroma nefrotik

6. Gastrointestinal: mual, muntah, nyeri abdomen

7. Paru-paru: pleurisy, hipertensi pulmonal,lesi parenkhim paru.

8. Jantung: perikarditis, endokarditis, miokarditis

9. Retikulo-endotel: organomegali (limfadenopati, splenomegali, hepatomegali)

10. Hematologi: anemia, leukopenia, dan trombositopenia

11. Neuropsikiatri: psikosis, kejang, sindroma otak organik mielitis transversus,gangguan kognitif neuropati kranial dan perifer.

Batasan operasional diagnosis SLE yang dipakai dalam rekomendasi ini diartikan sebagai terpenuhinya kriteria minimum (definitif) atau banyak kriteria terpenuhi (klasik) yang mengacu pada kriteria dari the American College of Rheumbatology (ACR) revisi tahun 1997. Terkait dengan dinamisnya perjalanan penyakit SLE, maka diagnosis dini tidaklah mudah ditegakkan. SLE pada tahap awal, seringkali bermanifestasi sebagai penyakit lain misalnya artritis reumatoid, gelomerulonefritis, anemia, dermatitis dan sebagainya. Ketepatan diagnosis dan pengenalan dini penyakit SLE menjadi penting.

Tabel 1. Kriteria diagnosis SLE

\begin{tabular}{|c|c|}
\hline Kriteria & Batasan \\
\hline Ruam malar & $\begin{array}{l}\text { Eritema yang menetap, rata atau menonjol, pada daerah malar dan } \\
\text { cenderung tidak melibatkan lipat nasolabial }\end{array}$ \\
\hline Ruam diskoid & $\begin{array}{l}\text { Plak eritema menonjol dengan keratolitik dan sumbatan folikular. } \\
\text { Pada SLE lanjut dapat ditemukan parut atrofi }\end{array}$ \\
\hline Fotosensitifitas & $\begin{array}{l}\text { Ruam kulit yang diakibatkan reaksi abnormal terhadap sinar } \\
\text { matahari, baik dari anamnesis pasien atau yang dilihat oleh dokter } \\
\text { pemeriksa }\end{array}$ \\
\hline Ulkus mulut & $\begin{array}{l}\text { Ulkus mulut atau orofaring, umumnya tidak nyeri dan dilihat oleh } \\
\text { dokter pemeriksa. }\end{array}$ \\
\hline Artritis & $\begin{array}{l}\text { Artritis non erosif yang melibatkan dua atau lebih sendi perifer, } \\
\text { ditandai oleh nyeri tekan, bengkak atau efusia }\end{array}$ \\
\hline Serositis & Riwayat nyeri pleuritik atau pleuritic friction rub yang didengar oleh \\
\hline Pleuritis & dokter pemeriksa atau terdapat bukti efusi pleura. Atau \\
\hline Perikarditis & Terbukti dengan rekaman EKG atau pericardial friction rub atau \\
\hline
\end{tabular}




\begin{tabular}{|c|c|}
\hline & terdapat bukti efusi perikardium. \\
\hline Gangguan renal & $\begin{array}{l}\text { a. Proteinuria menetap }>0.5 \text { gram per hari atau }>3+\text { bila tidak } \\
\text { dilakukan pemeriksaan kuantitatif, atau } \\
\text { b. Silinder seluler : - dapat berupa silinder eritrosit, hemoglobin, } \\
\text { granular, tubular atau campuran }\end{array}$ \\
\hline \multirow[t]{2}{*}{ Gangguan neurologi } & $\begin{array}{l}\text { a. Kejang yang bukan disebabkan oleh obat-obatan atau gangguan } \\
\text { metabolik (misalnya uremia, ketoasidosis, atau ke dak- } \\
\text { seimbangan elektrolit)., atau }\end{array}$ \\
\hline & $\begin{array}{l}\text { b. Psikosis yang bukan disebabkan oleh obat-obatan atau gangguan } \\
\text { metabolik (misalnya uremia, ketoasidosis, atau ke dak- } \\
\text { seimbangan elektrolit). }\end{array}$ \\
\hline \multirow{6}{*}{$\begin{array}{l}\text { Gangguan } \\
\text { hematologik }\end{array}$} & a. Anemia hemolitik dengan retikulosis, atau \\
\hline & b. Lekopenia $<4.000 / \mathrm{mm} 3$ pada dua kali pemeriksaan atau lebih \\
\hline & Atau \\
\hline & c. Limfopenia $<1.500 / \mathrm{mm} 3$ pada dua kali pemeriksaan atau lebih \\
\hline & Atau \\
\hline & $\begin{array}{l}\text { d. Trombositopenia }<100.000 / \mathrm{mm} 3 \text { tanpa disebabkan oleh obat- } \\
\text { obatan }\end{array}$ \\
\hline \multirow[t]{5}{*}{ Gangguan imunologik } & $\begin{array}{l}\text { Anti-DNA: antibodi terhadap native DNA dengan titer yang } \\
\text { abnormal, atau }\end{array}$ \\
\hline & $\begin{array}{l}\text { b. Anti-Sm: terdapatnya antibodi terhadap antigen nuklear Sm } \\
\text { atau }\end{array}$ \\
\hline & $\begin{array}{l}\text { c. Temuan positif terhadap antibodi anti fosfolipid yang didasarkan } \\
\text { atas: }\end{array}$ \\
\hline & $\begin{array}{l}\text { 1) kadar serum antibodi antikardiolipin abnormal baik } \operatorname{IgG} \text { atau } \operatorname{IgM} \text {, } \\
\text { 2) Tes lupus antikoagulan positif menggunakan metoda standard, } \\
\text { atau }\end{array}$ \\
\hline & $\begin{array}{l}\text { 3) hasil tes serologi positif palsu terhadap sifilis sekurang-kurangnya } \\
\text { selama } 6 \text { bulan dan dikonfi rmasi dengan test imobilisasi Treponema } \\
\text { pallidum atau tes fl uoresensi absorpsi antibodi treponema }\end{array}$ \\
\hline $\begin{array}{l}\text { Antibodi anti nuklear } \\
\text { positif (ANA) }\end{array}$ & $\begin{array}{l}\text { Titer abnormal dari antibodi anti-nuklear berdasarkan pemeriksaan } \\
\text { imunofl uoresensi atau pemeriksaan setingkat pada setiap kurun } \\
\text { waktu perjalan penyakit tanpa keterlibatan obat yang diketahui } \\
\text { berhubungan dengan sindroma lupus yang diinduksi obat. }\end{array}$ \\
\hline
\end{tabular}

Bila dijumpai 4 atau lebih kriteria di atas, diagnosis SLE memiliki sensitifitas $85 \%$ dan spesifisitas 95\%. Sedangkan bila hanya 3 kriteria dan salah satunya ANA positif, maka sangat mungkin SLE dan diagnosis bergantung pada pengamatan klinis. Bila hasil tes ANA negatif, maka kemungkinan bukan SLE. Apabila hanya tes ANA positif dan manifestasi klinis lain tidak ada, maka belum tentu SLE, dan observasi jangka panjang diperlukan. 


\section{Peran Respon Imunitas Humoral pada SLE}

Penyakit SLE berkaitan dengan sejumlah besar abnormalitas imunoregulator. Penelitian banyak yang berfokus pada abnormalitas respon sel $\mathrm{T}$ atau produksi sitokin sel $\mathrm{T}$ dan atau defek kontrol oleh sel T regulatorik. Data terkini menunjukkan bahwa ada tendensi intriksi dari sel B untuk merespon secara berlebihan terhadap stimulasi imun yang merupakan gambaran penting dari SLE. Salah satu gambaran dari hipotesis sel B ini adalah hubungan sentral antara SLE dan produksi autoantibodi khas yang beberapa di antaranya terlibat dalam kerusakan jaringan. ${ }^{7}$ Pada penyakit SLE, terdapat bukti bahwa patologi jaringan diperantarai oleh autoantibodi, meskipun aktifitas sel B abnormal atau fungsinya justru berkontribusi terhadap perkembangan penyakit. Hal ini meliputi antara lain:

a. abnormalitas aktivasi sel $\mathrm{B}$,

b. sinyaling dan migrasi sehingga meningkatkan ekspresi dari molekul ko-stimulator seperti ligand bagi CD40 (CD154)

c. meningkatkan produksi beberapa sitokin (IL-6 dan IL-10) yang menstimulasi fungsi sel B

d. meningkatkan aktifitas mutasi

e. Abnormalitas seleksi positif dan negatif dari sel B yang secara langsung maupun tidak langsung berkontribusi terhadap perkembangan penyakit autoimun

Temuan terbaru bahwa peran sel B dalam sistem imun tidak hanya sebagai prekursor dari sel penyekresi antibodi (Gambar 2a). Sel B mempunyai fungsi esensial dalam meregulasi respon imun, yaitu:

a. Limfotoksin $\alpha / \beta$ yang diekspresikan oleh sel B penting bagi diferensiasi sel dendritik folikular pada organ limfoid sekunder

b. Antigen-presenting $\mathrm{M}$ cells tidak akan berkembang di mukosa gastrointestinal apabila tidak ada sel B

c. Sel B aktif mengekspresikan molekul ko-stimulator yang esensial bagi evolusi efektor sel T

d. Sel B itu sendiri mampu berdiferensiasi menjadi sel efektor penghasil sitokin terpolar yang mempengaruhi diferensiasi sel efektor sel T

e. Sitokin yang dihasilkan oleh sel B aktif berkontribusi bagi respon imun dengan cara bekerja sebagai antigen-presenting dendritic cells

Secara bersamaan, hal ini mengindikasikan bahwa sel $B$ berperan penting dalam organogenesis limfoid sama halnya dengan inisiasi dan regulasi respon sel $\mathrm{T}$ dan sel $\mathrm{B}$. 
Aktifitas sel B berlebihan dan tidak terkontrol dapat meningkatkan aktifitas sistem imun yang dapat menjadi autoimunitas. $^{7}$

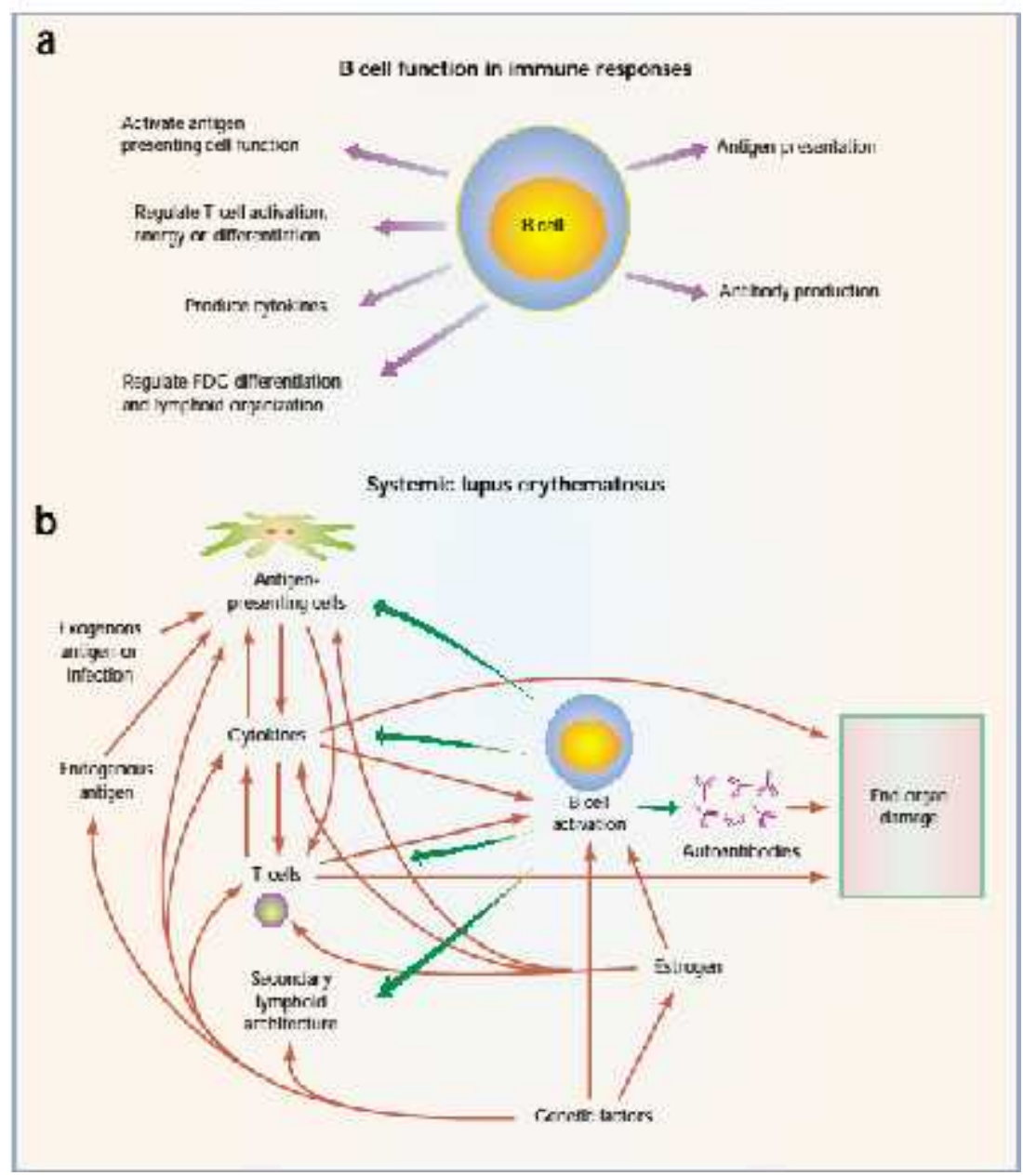

Gambar 2. Regulasi sel B pada respon imun normal dan gangguan potensial pada $\mathrm{SLE}^{7}$

Karakteristik dari SLE adalah produksi sejumlah autoantibodi IgG dan IgM yang secara langsung melawan satu atau lebih dari komponen nuklear, seringkali berupa double stranded (ds) DNA dan atau single stranded (ss) DNA. Baik anti-dsDNA dan anti-ssDNA terlibat dalam perkembangan penyakit. Lupus seperti autoimunitas lain terjadi karena hiperaktifitas dari sel B dengan minimal atau tanpa kontribusi dari sel limfosit $\mathrm{T}^{8}$

Gambaran sentral dari SLE adalah kecenderungan untuk menghasilkan autoantibodi IgG dengan aviditas tinggi terhadap DNA yang mempunyai potensi patogenik. Tentu saja, banyak dari gen Ig yang mengkodekan autoantibodi terhadap DNA sudah bermutasi berat. Backmutation dari gen Ig menjadi sekuens germline menyebabkan hilangnya kapasitas anti-DNAbinding. Temuan ini mengindikasikan bahwa autoantibodi patogenik berasal dari aktivitas hipermutasi somatik. Data tersebut juga menyatakan bahwa autoantibodi dapat terjadi dari gen Ig yang tidak mempunyai kapasitas untuk mengikat DNA sebelum induksi dari suatu 
respon imun. Hasil ini menganggap bahwa autoantibodi dapat tidak muncul karena sistem imun distimulasi oleh autoantigen DNA, namun autoantibodi diakibatkan oleh stimulasi dari antigen lain atau oleh suatu aktivator poliklonal yang menginduksi hipermutasi somatik. ${ }^{7}$

Pada subjek manusia dan mencit hewan model SLE, keduanya menghasilkan sejumlah autoantibodi yang melawan kompleks nuklear dan komponen dari nukleosom, meskipun profil dari autoantibodi ini dapat beragam antara subjek dan hewan coba. Abnormalitas imunologik pada hewan coba SLE dan manusia adalah adanya hiperreaktifitas sel B poliklonal. Analisis menggunakan flow cytometry menunjukkan gangguan maturasi dan diferensiasi sel B pada penderita SLE. Data ini menghasilkan informasi baru tentang perubahan pada diferensiasi sel B melibatkan imunopatologi atau sekunder terjadi karena inflamatori lingkungan. ${ }^{7}$

\section{Cell Dependent Generation of High Avidity Autoantibodies}

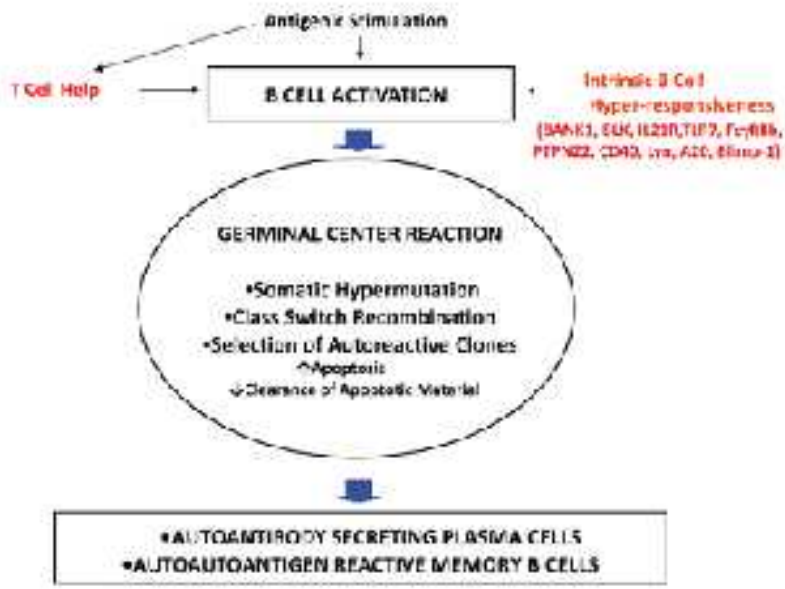

\section{Gambar 3. Skema potensi kelainan aktivasi sel B dependen sel T pada SLE ${ }^{9}$}

Pengetahuan tambahan didapatkan dari pengaruh terapi terhadap aktifitas klinis penyakit atau efek terhadap abnormalitas subset sel B pada penyakit SLE. Selain itu, pemahaman tentang peran penting dari sel B dalam patogenesis SLE menjadikan peluang untuk memantau subset sel B spesifik sebagai biomarker dari aktifitas penyakit dan respon klinis terhadap terapi. ${ }^{9}$

Mutasi somatik proses unik pada sel B yang memfasilitasi mutasi pada variable region dari gen Ig dengan angka mutasi 1 perubahan/ribuan nukleotida per generasi atau mendekati 1 juta kali angka mutasi gen lain. Normalnya, autoantibodi yang muncul karena aktivitas mutator sel B akan dihapus, mengalami anergi atau diarahkan untuk perbaikan reseptor. Namun, pada pasien SLE, overaktivitas sel B secara umum dapat meliputi mekanisme normal yang menyingkirkan repertoir autoantibodi Ig yang sudah mengalami mutasi. Tingginya sifat mutasi dari autoantibodi Ig patogenik terhadap DNA pada SLE berasal dari reaksi pusat 
germinal. Hal ini mungkin juga karena beberapa autoantibodi muncul selama respon independen sel T pada zona marginal dari sel B. Pada beberapa pasien SLE, lingkungan mikro dari respon imun juga bisa abnormal dengan sel $\mathrm{T}$ persisten membantu dan atau defek pada pembersihan materi apoptotik yang mengakibatkan seleksi positif dari sel B autoreaktif (Gambar 2b). ${ }^{7}$

\section{Subset Sel B pada SLE}

Abnormalitas dari subset populasi sel B perifer pada SLE ditemukan pada pasien SLE. Perbedaan dengan orang sehat menunjukkan bahwa mekanisme yang mengontrol banyak aspek dari biologi sel B (maturasi sel B pre-imun, seleksi negatif dan receptor editing) dan aspek respon antigen (hipermutasi somatik dan efektor sel B) bersifat abnormal pada pasien SLE. Sejumlah perubahan pada populasi sel B pre imun di darah perifer juga ditemukan pada pasien SLE yaitu sel B transisional, sel B pre nä̈ve dan nä̈ve. Populasi ini menunjukkan stadium mayor dari maturasi sel B yang terjadi di sumsum tulang. Pada SLE, baik sel B transisional dan sel B pre naïve meningkat pesat. Populasi ini dapat diperiksa dengan sejumlah marker seperti CD38, CD5, Cd9, CD10, CD24 dan ABCB1 transporter. Hasil ini mengindikasikan bahwa terjadi pergeseran populasi dalam kompartemen sel B pre imun pada SLE ke sel B imatur dan pergeseran ini independen terhadap aktifitas penyakit. ${ }^{9}$

Pada pasien dengan SLE inaktif juga ditemukan kegagalan untuk membuang sel B yang mengekspresikan self-reactive B-cell receptors (BCRs). Konsisten dengan hal ini, penelitian awal menunjukkan bahwa self-reactivity dan hilangnya seleksi yang tepat selama perkembangan sel B awal dari sel B naïve imatur $\left(\mathrm{CD} 10^{+} \mathrm{CD} 27^{-} \mathrm{IgM}^{+} \mathrm{B}\right.$ cells $)$ menjadi sel $\mathrm{B}$ naïve matur $\left(\mathrm{CD} 10^{-} \mathrm{CD} 27^{-} \operatorname{IgM}^{+} \mathrm{B}\right.$ cells $)$ merupakan gambaran dari SLE. ${ }^{10}$

\section{KESIMPULAN}

Peran penting sel B dalam meregulasi berbagai aspek reaksi imunitas dan kapasitasnya untuk berdiferensiasi menjadi sel penghasil autoantibodi, maka cukup beralasan untuk menganggap peningkatan fungsi sel B merupakan kejadian patogenik pada penyakit SLE. Hal ini dapat juga terjadi akibat variasi dari abnormalitas genetik.

\section{DAFTAR PUSTAKA}

1. Gill JM., Quisel AM., Rocca PV., Walters DT. Diagnosis of Systemic Lupus Erythematosus. American Academy of Family Physicians 2003. Available URL: http://www.aafp.org/afp. 
2. Kajsmir YI, et al. Diagnosis dan Pengelolaan Lupus Eritematosus Sistemik. Rekomendasi Perhimpunan Reumatologi Indonesia 2011.

3. Bertsias G., Cervera R., Boumpas DT. Systemic Lupus Erythematosus: Pathogenesis and Clinical Features. Available from: URL:http://eular.org.

4. Lisnevskaia L, Murphy G, Isenberg D. Systemic lupus erythematosus. The lancet 2014. 111.

5. Mak A, Tay SH. Environmental Factors, Toxicants and Systemic Lupus Erythematosus. Int. J. Mol. Sci 2014. 15. 16043-16056.

6. Mok CC, Lau CS. Pathogenesis of systemic lupus erythematosus. J Clin Pathol 2003. $56: 481-490$.

7. Lipsky P. Systemic lupus erythematosus: an autoimmune disease of B cell hyperactivity. Nature immunology 2001. 2(9): 763-765.

8. Krishnamurthy S., Mahadevan S. Systemic Lupus Erythematosus: Recent Concepts in Genomics, Pathogenetic Mechanisms, and Therapies. International Scholarly Research Network ISRN Immunology 2011. doi:10.5402/2011/868964.

9. Dörner T., Giesecke C., Lipsky PE. Mechanisms of B cell autoimmunity in SLE. Arthritis Research \& Therapy 2011. 13:243.

10. Yurasov S, Wardemann H, Hammersen J, Tsuiji M, Meffre E, Pascual V, Nussenzweig MC. Defective B cell tolerance checkpoints in systemic lupus erythematosus. J Exp Med 2005. 201:703-711. 